\title{
PENGARUH PEMBERIAN BEBERAPA JENIS PUPUK KANDANG TERHADAP PERTUMBUHAN AWAL RUMPUT GAJAH (Pennisetum purpureum)
}

\author{
Dominggus de Lima*, Lili Yoris \\ Jurusan Peternakan Fakultas Pertanian, Universitas Pattimura \\ Jln. Ir. M. Putuhena, Kampus Poka, Ambon, Kode Pos. 97233 \\ *Email : $\underline{\text { fildad@gmail.com }}$
}

\begin{abstract}
ABSTRAK
Penelitian ini bertujuan untuk mengetahui efek penggunaan pupuk kandang yang berbeda terhadap pertumbuhan awal rumput gajah (Pennisetum purpureum). Penelitian ini dilaksanakan di lahan kebun hijauan makanan ternak Jurusan Peternakan Fakultas Pertanian Unpatti. Variabel yang diamati dalam penelitian ini adalah: jumlah tunas, lebar daun, panjang daun dan tinggi tanaman. Rancangan yang digunakan dalam penelitian ini adalah Rancangan Acak Lengkap dengan tiga perlakuan dan lima ulangan. Hasil penelitian menunjukan bahwa pengaruh perlakukan berbeda sangat nyata terhadap jumlah tunas, panjang daun, tinggi tanaman dan lebar daun berpengaruh nyata. Dapat disimpulkan bahwa penggunaan pupuk kotoran kambing dengan dosis 20 ton/ha memberikan pengaruh yang baik terhadap pertumbuhan awal rumput rumput gajah (Pennisetum purpureum).
\end{abstract}

Kata kunci: Pupuk kandang, fase pertumbuhan awal, rumput gajah (Pennisetum purpureum)

\section{EFFECT OF DIFFERENTS COMPOST ON EARLY GROWTH ELEPHANT GRASS (Pennisetum purpureum)}

\begin{abstract}
The objective of the research was to determine the effects of different compost application on the early growth of elephant grass (Pennisetum purpureum). The research was conducted at educational field of Animal Husbandry section of Agriculture Faculty Pattimura University. The measurements were number of buds, lesf wide, leaf length and plant height. The research was arranged into Complete Randomized Design with three treatments and five replication. The results showed that there was a highly significant difference on number of buds, leaf length, plant height and leaf wide. It was concluded that the application of 20 tones/ha goat compost produced good effect on early growth of elephant grass (Pennisetum purpureum).
\end{abstract}

Key words: Compost, early growth phase, elephant grass (Pennisetum purpureum)

\section{PENDAHULUAN}

Hijauan merupakan bahan pakan yang sangat penting dalam usaha ternak potong khususnya ternak ruminansia, sebab hijauan mengandung hampir semua zat makanan yang diperlukan untuk kebutuhan hidup pokok, pertumbuhan, produksi dan reproduksi seekor ternak. Penanaman hijauan makanan ternak (HMT) dan pembudidayaan hijauan jenis unggul merupakan salah satu faktor penting untuk memperoleh produksi hijauan yang selalu tersedia, baik kualitas maupun kuantitasnya. Sitindaon (2013), menyatakan bahwa hijauan yang biasanya digunakan sebagai pakan pada usaha peternakan di pedesaan adalah rumput lapangan dan hasil sampingan pertanian serta beberapa jenis rumput unggul.

Penyediaan hijauan makanan ternak harus cukup dan kontinu dalam arti harus tersedia sepanjang tahun. Ketersediaan makanan ternak dapat dilakuakan dengan cara menanamkan hijauan pakan ternak yang berkualitas unggul seperti rumput gajah (Pennisetum purpureum) yang merupakan salah satu jenis rumput unggul yang telah dikenal keunggulannya seperti produksinya relatif tinggi, umur panennya pendek, tahan terhadap kekeringan dan responsif terhadap pemupukan.

Tujuan penanaman hijauan makanan ternak yang unggul adalah untuk memperoleh produksi hijauan makanan ternak yang selalu tersedia dalam jumlah yang cukup untuk kebutuhan ternak. Penanaman hijauan makanan ternak harus dipilih jenisjenis tanaman yang sifatnya menguntungkan misalnya produktifitas per satuan luas cukup tinggi, nilai palatabilitasnya cukup baik, toleransi terhadap lingkungan, mudah dikembangbiakan serta nilai gizinya cukup tinggi (Aryanto dan Polakitan, 2009). 
Subowo (2010), menyatakan bahwa dukungan kesuburan tanah untuk pertumbuhan tanaman sangat penting untuk peningkatan produktifitas panen. Penggunaan pupuk merupakan salah satu alternatif untuk meningkatkan pertumbuhan rumput gajah, karena pupuk mengandung unsur-unsur hara yang di perlukan pertumbuhan tanaman. Pupuk kandang dapat mempertahankan bahan organik tanah, meningkatkan aktifitas biologis dan juga meningkatkan ketersediaan air. Semakin tinggi kadar air tanah maka absorbsi dan transportasi unsur hara maupun air akan lebih baik, sehingga laju fotosintesis untuk dapat menghasilkan cadangan makanan bagi pertumbuhan tanaman lebih terjamin dan produksinya pun akan meningkat (Ifradi dan Elsifitriana, 2003).

Pemberian pupuk kandang dapat menambah unsur hara makro dan mikro, meningkatkan kapasitas menahan air, meningkatkan kemampuan pertukaran kation serta dapat meningkatkan $\mathrm{pH}$ tanah. Pupuk kandang kambing mengandung 1,7\% Nitrogen, 0,80 $\%$ Phospor dan 0,90\% Kalium, sedangkan pupuk kandang ayam mengandung $1,5 \%$ Nitrogen, 0,7 \% Phospor, dan 0,89 \% Kalium ( Purbayanti, 2013 ).

Hijauan makanan ternak dapat dipupuk dengan pupuk buatan atau pupuk organik. Penggunaan dengan pupuk organik seperti pupuk kandang hendaknya dilakukan bersamaan pada saat pengolahan tanah, walaupun kandungan unsur hara pupuk kandang tidak sebesar pupuk buatan tetapi mempunyai kelebihan yaitu dapat memperbaiki sifat fisik tanah dan kimia tanah serta mendorong kehidupan jasad renik tanah. Dengan kata lain pupuk kandang mempunyai kemampuan mengubah berbagai faktor dalam tanah, sehingga menjadi faktor-faktor yang menjamin kesuburan tanah.

Kotoran ternak pada usaha-usaha peternakan di Maluku belum dimanfaatkan secara optimal untuk meningkatkan produksi hijauan makanan ternak. Umumnya kotoran ternak yang dihasilkan berdampak negatif bagi masyarakat. Agar tidak mencemari lingkungan maka perlu adanya pemanfaatan kotoran hewan sebagai pupuk dalam usaha pertanian atau sebagai peningkatan kualitas hijauan makanan ternak.

Penelitian ini bertujuan untuk mengetahui pengaruh penggunaan pupuk kandang yang berbeda terhadap pertumbuhan awal rumput gajah ( Pennisetum purpureum ).

\section{BAHAN DAN METODE}

Penelitian ini berlangsung selama tiga (3) bulan dan dilaksanakan di lahan kebun hijauan makanan ternak (HMT) Jurusan Peternakan Fakultas Pertanian Universitas Pattimura. Alat yang digunakan dalam penelitian ini adalah perlengkapan pengolahan tanah, timbangan, meteran, alat tulis serta keperluan lapangan lainnya. Bahan yang digunakan dalam penelitian ini adalah bibit rumput gajah dalam bentuk stek, pupuk kandang kotoran kambing, dan pupuk kandang kotoran ayam.

Persiapan media tanah dan tanaman, tanah yang diolah kemudian dibuat bedengan dengan ukuran lebar $1,25 \mathrm{~m}$, panjang $3,75 \mathrm{~m}$ dan tinggi $15 \mathrm{~cm}$. Pupuk kandang kambing dan ayam yang diambil kemudian disimpan selama 15 hari agar terurai secara alami. Bahan tanaman berupa stek rumput gajah. Stek yang diambil memiliki 2 ruas dan 3 buku dengan ukuran panjang 20-25 cm. Sebelum penanaman, tanah dicampur dengan pupuk kandang ayam (P1) dan pupuk kandang kambing (P2), sampai merata. Penanaman dilakukan 2 minggu setelah pengolahan tanah dengan jarak tanam 80 × $80 \mathrm{~cm}$. Stek rumput gajah ditanam sesuai dengan jarak tanam di bedengan sedalam 1 ruas setengah dari 3 buku stek. Pemeliharaan yang dilakukan meliputi penyiraman dan pembersihan gulma pada pagi dan sore hari. Pembersihan gulma dilakukan dengan pembersihan terhadap rumputrumput yang tumbuh di dalam bedengan.

Pengambilan data setiap perlakuan dilakukan per minggu selama 60 hari. Variabel yang diamati dalam penelitian ini meliputi: (1) jumlah tunas, dihitung jumlah tunas yang diamati pada masingmasing ruas; (2) panjang daun, diukur dari ketiak daun sampai ujung daun; (3) lebar daun, diukur dari tepi kiri daun ke tepi kanan daun; dan (4) tinggi tanaman, diukur dari permukaan tanah sampai ujung daun tertinggi pada waktu ditegakan.

Penelitian ini menggunakan Rancangan Acak Lengkap ( RAL ) dengan tiga (3) perlakuan yaitu: P0 (tanpa penggunaan pupuk kandang), P1 (pupuk kotoran ayam) dan P2 (pupuk kotoran kambing). Masing-masing perlakuan diulang sebanyak delapan (8) kali. Bila terdapat pengaruh perlakuan dalam analisis ragam RAL, maka dilanjutkan dengan menggunakan Uji Beda Nyata Terkecil (BNT). Data yang diperoleh ditabulasi, kemudian dianalisis menggunakan software Microsoft Office Excel 2007. Model matematika dari rancangan acak lengkap yang digunakan menurut petunjuk Steel dan Torrie ( 1993 ) sebagai berikut:

$$
Y_{i j}=\mu+\tau_{i}+e_{i j} ; i=1,2,3 \text { dan } j=1,2, \ldots, 8
$$

Keterangan :

$\mathrm{Y}_{\mathrm{ij}}$ : Respons yang diamati (jumlah tunas, panjang daun, lebar daun, atau tinggi tanaman) yang memperoleh perlakuan ke-i pada ulangan ke-j.

$\mu \quad$ : Nilai rataan umum.

$\tau_{\mathrm{i}} \quad$ : Pengaruh penggunaan pupuk kandang ke-i.

$\mathrm{e}_{\mathrm{ij}}$ : galat percobaan.

\section{HASIL DAN PEMBAHASAN}

\section{Jumlah Tunas}

Hasil penelitian menunjukkan bahwa rata-rata jumlah tunas terbanyak adalah perlakuan P2 sebanyak 22,6 tunas, diikuti oleh P1 sebanyak 15,2, dan P0 
sebanyak 11 tunas. Hasil analisis ragam menunjukkan bahwa terdapat perbedaan yang sangat nyata $(\mathrm{p}<0,01)$ pengaruh penggunaan pupuk kandang terhadap jumlah tunas. Uji Beda Nyata Terkecil menunjukkan bahwa perlakuan P0 berbeda nyata terhadap P1, dan P2, serta P1 berbeda sangat nyata terhadap P2 (Gambar 1).

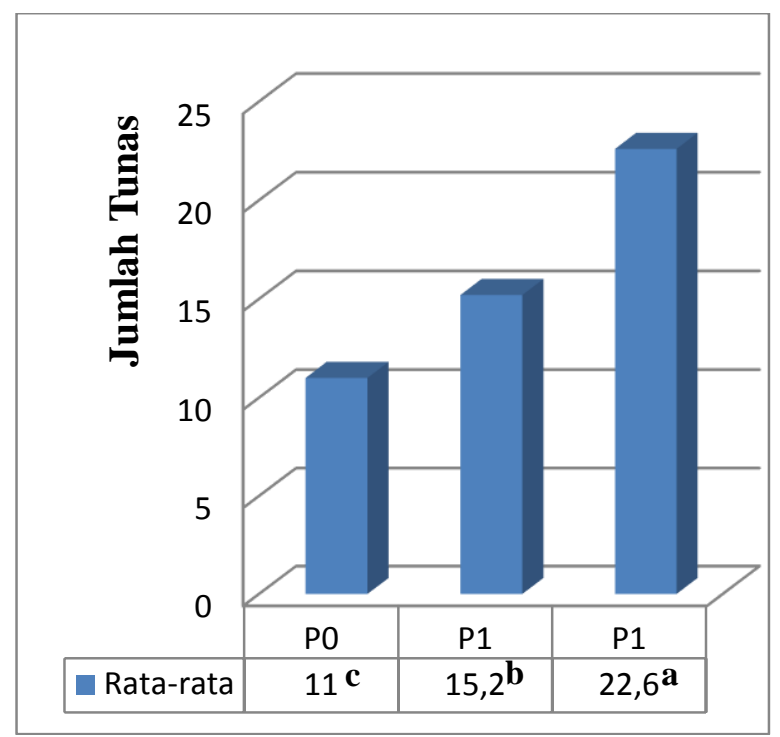

Keterangan : Superscript yang berbeda menunjukkan perbedaan yang sangat nyata $(\mathrm{p}<0,01)$

Gambar 1. Bar chart pengaruh jenis pupuk kandang terhadap jumlah tunas rumput gajah

Banyaknya tunas pada P2, diduga karena pupuk kandang kambing mempunyai peranan yang lebih baik dalam hal memperbaiki unsur hara tanah dibanding pupuk lainnya, sehingga pertumbuhan tunas yang muncul semakin banyak. Kusuma (2014) menyatakan bahwa pemberian pupuk kandang pada kondisi lahan yang kurang unsur hara, sangat baik karena penambahan pupuk kandang dalam tanah akan memperbaiki sifat fisik tanah lebih remah dan meningkatkan jumlah pori-pori tanah sehingga memudahkan tunas-tunas baru tumbuh menembus permukaan tanah.

Pertumbuhan rumput gajah dimulai dengan keluarnya tunas berbentuk taji pendek pada umur kurang dari satu minggu, bersama dengan itu pada buku-buku stek akan keluar akar (Nasarudin dan Rosmawati, 2011). Tunas muncul bukan saja dari ruas stek di permukaan tanah tetapi juga ada tunas yang keluar dari ruas stek yang ada di dalam tanah.

Unsur hara nitrogen yang dikandung dalam pupuk kandang kambing yang sudah dikomposkan sangat baik kegunaannya bagi tanaman untuk pertumbuhan dan perkembangan daun tanaman lebih hijau segar dan banyak mengandung butir-butir hijau daun (klorofil) yang mempunyai peranan sangat penting dalam proses fotosintesis, mempercepat pertumbuhan tanaman serta menambah kandungan protein tanaman. Hidayat (2012) menyatakan bahwa pertambahan jumlah tunas salah satunya dipengaruhi oleh faktor jumlah nitrogen yang ada di dalam tanah. Nitrogen berfungsi untuk membentuk klorofil dan protein, dengan meningkatnya jumlah klorofil maka aktifitas fotosintesis akan meningkat.

Meningkatnya fotosintesis akan menyediakan energi yang lebih untuk dapat memacu hormon pertumbuhan dalam membentuk tunas baru. Menurut Sutejo (2002), fungsi nitrogen yaitu meningkatkan pertumbuhan tanaman, meningkatkan pertumbuhan daun tanaman semakin lebar dengan warna daun lebih hijau, meningkatkan kadar protein dalam tubuh tanaman, dan meningkatkan kualitas tanaman penghasil daun-daunan.

Selain itu banyaknya jumlah tunas pada perlakuan P2 juga dipengaruhi oleh ketersediaan unsur hara di dalam tanah, dan kemampuan akar untuk menyerap unsur hara serta kandungan gizi yang ada di dalam stek. Hal ini sesuai dengan apa yang dikatakan oleh Janick (1972), stek yang mengandung karbohidrat lebih tinggi dari nitrogen sehingga mengakibatkan stimulasi pertumbuhan akar dan sebaliknya bila kandungan nitrogen lebih tinggi dibandingkan karbohidrat maka akan mengakibatkan stimulasi pertumbuhan tunas.

\section{Panjang Daun}

Hasil penelitian menunjukkan bahwa rata-rata panjang daun dari yang paling panjang adalah perlakuan P2 sebesar 121,6 cm, dan diikuti oleh P1 sebesar 80,4, dan P0 sebesar 59,8 cm. Hasil analisis menunjukkan bahwa pengaruh perlakuan berbeda sangat nyata $(\mathrm{p}<0,01)$ terhadap panjang daun. Uji beda nyata terkecil membuktikan bahwa perlakuan P2 berbeda sangat nyata terhadap P1 dan P0 (Gambar 2).

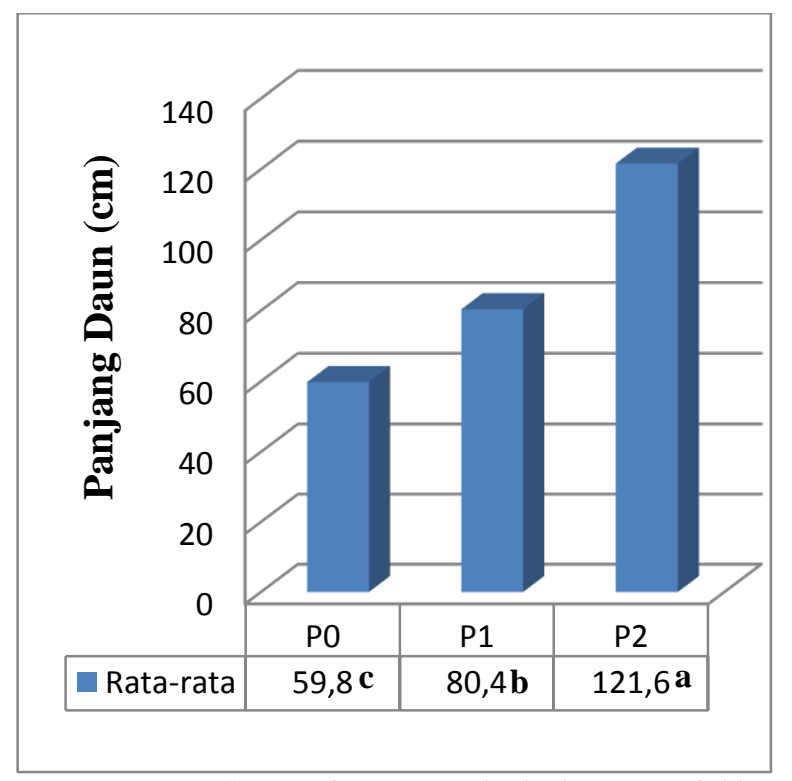

Keterangan : Superscript yang berbeda menunjukkan perbedaan yang sangat nyata $(\mathrm{p}<0,01)$

Gambar 2. Bar chart pengaruh jenis pupuk kandang terhadap panjang daun rumput gajah 
Berdasarkan pengamatan menunjukkan bahwa terlihat perbedaan ukuran panjang daun pada masingmasing perlakuan. Hal ini dapat dilihat pada perbedaan rataan panjang daun secara berurutan dari yang terendah terdapat pada perlakuan $\mathrm{P} 0$, diikuti dengan perlakuan P1, dan P2 yang terpanjang perlakuan P2. Perbedaan ukuran rataan panjang daun ini terjadi karena adanya perlakuan pupuk kandang yang berbeda pada setiap perlakuan, sehingga jelas berbeda kandungan unsur haranya yang terdapat dalam tanah.

Aryanto dan Polakitan (2009), mengatakan bahwa besarnya persentasi pertumbuhan sangat tergantung pada ketersediaan unsur hara di dalam tanah, khususnya nitrogen dan bahan organik juga berpengaruh langsung terhadap fisiologi tanaman seperti meningkatkan respirasi untuk merangsang serapan unsur hara sehingga meningkatkan pertumbuhan dan produksi tanaman tersebut. Ayu (2008) menyatakan bahwa pupuk organik berupa pupuk kandang dapat merangsang pertumbuhan akar, batang dan daun pada tanaman.

\section{Lebar Daun}

Hasil penelitian menunjukkan bahwa rata-rata lebar daun berturut-turut adalah perlakuan P2 sebesar $4,88 \mathrm{~cm}$, diikuti oleh P1 sebesar $4,0 \mathrm{~cm}$, dan P0 sebesar 2,64 cm seperti terlihat pada Gambar 3 .

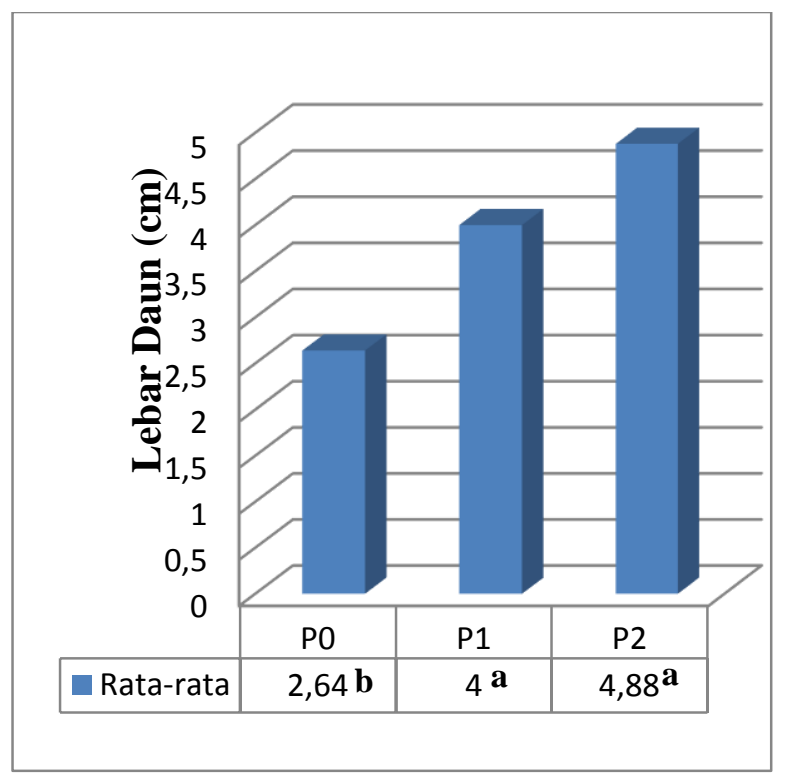

Keterangan : Superscript yang berbeda menunjukkan perbedaan yang nyata $(\mathrm{p}<0,05)$

Gambar 3. Bar chart pengaruh jenis pupuk kandang terhadap lebar daun rumput gajah

Hasil analisis ragam menunjukkan bahwa pengaruh perlakuan berbeda nyata $(\mathrm{p}<0,05)$ terhadap lebar daun rumput gajah. Uji beda nyata terkecil membuktikan bahwa perlakuan P2 berbeda sangat nyata terhadap P0, namun tidak berbeda nyata terhadap P1 (Gambar 3). Hal ini disebabkan karena adanya pengaruh perbedaan unsur hara pada setiap perlakuan pupuk kandang yang diberikan terutama kandungan unsur hara nitrogen, dimana unsur hara nitrogen yang dikandung di dalam pupuk kandang sangat besar kegunaannya bagi tanaman untuk pertumbuhan dan perkembangan.

Ifradi dan Elsifitriani (2003) yang menyatakan bahwa nitrogen dapat meningkatkan pertumbuhan tanaman dengan daun tanaman yang lebar serta warna yang lebih hijau, meningkatkan kadar protein dalam tanaman, serta meningkatkan kualitas tanaman penghasil daun dengan jumlah yang lebih banyak.

\section{Tinggi Tanaman}

Hasil penelitian menunjukkan bahwa rata-rata tinggi tanaman rumput gajah berturut-turut adalah perlakuan P2 sebesar 177,20 cm, diikuti oleh P1 sebesar 174,6 cm, dan P0 sebesar 118,8 cm. Hasil analisis ragam menunjukkan bahwa pengaruh perlakuan berbeda sangat nyata $(p<0,01)$ terhadap tinggi tanaman. Uji beda nyata terkecil membuktikan bahwa perlakuan P2 berbeda sangat nyata terhadap P1 dan P0 (Gambar 4).

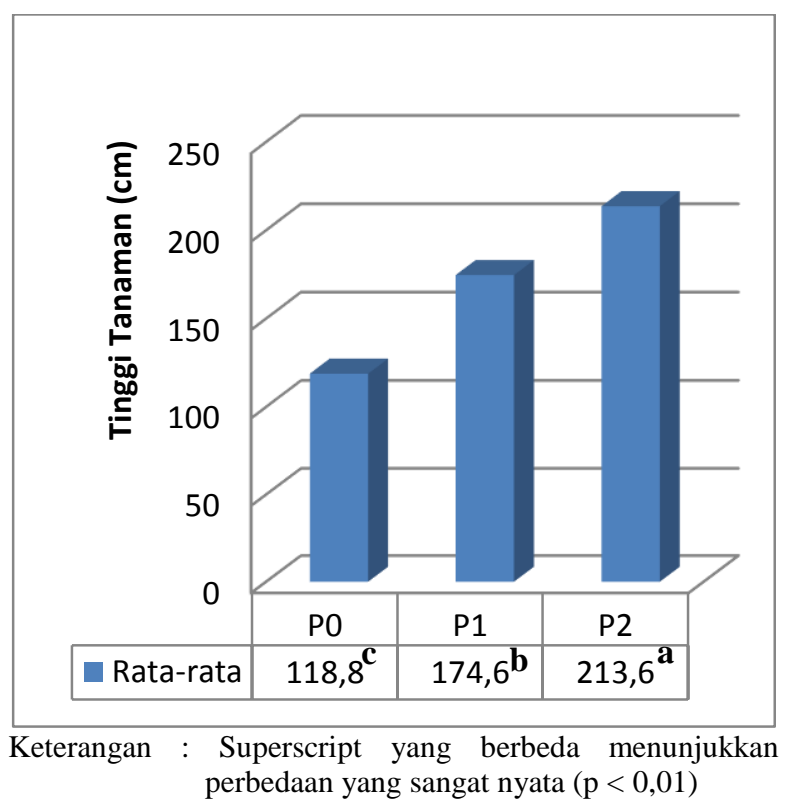

Gambar 4. Bar chart pengaruh jenis pupuk kandang terhadap tinggi tanaman rumput gajah

Perlakuan P2 dari data yang diperoleh mempunyai pertambahan tinggi tanaman yang lebih tinggi dibanding perlakuan P1 dan P0. Hal ini disebabkan karena pupuk kandang kambing mempunyai unsur hara yang baik sehingga dapat membantu pertumbuhan tinggi tanaman. Pertumbuhan tinggi tanaman juga jelas menunjukan adanya pengaruh dari peran kandungan unsur hara $\mathrm{N}, \mathrm{P}, \mathrm{K}$ dan hara makro sangat diperlukan dalam jumlah yang banyak bagi tanaman karena unsur hara makro merupakan penyusun protoplasma jaringan dan struktur tanaman. Selain itu unsur hara pada perlakuan P2 dapat meningkatkan pertumbuhan sehingga akan 
mempengaruhi tinggi tanaman. Sari (2012) menyatakan bahwa jumlah unsur hara yang diserap menentukan kecepatan pertumbuhan tinggi tanaman.

Meningkatnya tinggi tanaman pada perlakuan P2 disebabkan karena banyaknya tunas dan jumlah daun sehingga terjadi persaingan dalam memperolah sinar matahari dalam selama proses fotosintesis. Menurut Sumarsono dkk. (2009) menyatakan bahwa jumlah tunas dan banyaknya daun merupakan suatu faktor yang menentukan jumlah energi matahari yang dapat diserap oleh daun. Pemberian pupuk kandang sebagai bahan organik penyedia unsur hara akan mempengaruhi tinggi tanaman sehingga cahaya dapat dimanfaatkan semaksimal mungkin, maka akan diperoleh hasil fotosintesis yang semakin banyak.

Selain itu tinggi tanaman disebabkan karena kandungan $\mathrm{N}$ pada pupuk kandang kambing sehingga nitrogen yang diberikan pada konsentrasi yang tepat dapat merangsang pertumbuhan tanaman. Menurut Setiawan (2005), unsur nitrogen $(\mathrm{N})$ berfungsi untuk merangsang pertumbuhan tanaman secara keseluruhan, terutama batang tanaman. Unsur phosphor $(\mathrm{P})$ bagi tanaman lebih banyak berfungsi untuk merangsang pertumbuhan akar, khususnya akar tanaman muda. Unsur kalium (K) berperan dalam membentuk protein dan karbohidrat bagi tanaman. Menurut Ely dkk. (2014), selain faktor kesuburan tanah, tinggi tanaman dipengarui oleh faktor internal antara lain kualitas stek, waktu pemotongan, dan umur tanaman sedangkan faktor eksternal yang berpengaruh antara lain suhu, kelembaban, media tanam, penyinaran dan air.

\section{SIMPULAN DAN REKOMENDASI}

Berdasarkan penelitian yang dilakukan penggunaan pupuk kandang kambing memberikan pengaruh yang sangat nyata terhadap jumlah tunas, panjang daun, lebar daun, dan tinggi tanaman.

Guna memperbaiki lahan, meningkatkan hasil dan kualitas rumput gajah disarankan menggunakan pupuk kandang kambing, karena pupuk kandang kambing mengandung unsur-unsur hara yang baik untuk memperbaiki sifat fisik tanah dan biologis tanah sehingga tanaman rumput gajah dapat bertumbuh dengan baik dan hasilnya sangat memuaskan.

\section{DAFTAR PUSTAKA}

Aryanto, dan D. Polakitan. 2009. Uji Produksi Rumput Dwarf (Pennisetum purpureum) CV.Dwarf). Jurnal Ilmiah, Balai Pengkajian Teknologi Pertanian. Jl. Kampus Pertanian Kalasey, Manado, Sulawesi Utara.

Ayu, R. 2008. Cara Membuat Pupuk Organik, Untuk Tanaman Buah Dan Bunga yang Ramah Lingkungan. Jakarta: Pustaka Mina.

Ely, E., W. Eko dan Y.B.S. Heddy. 2014. Pengaruh Pupuk Kandang Sapi Pada Pertumbuhan Dan
Hasil Tanaman Terong (Solanum melongena) Pada Pola Tanam Tumpangsari Dengan Rumput Gajah (Penisetum purpureum) Tanaman Utama. Jurnal Produksi Tanaman. Vol 2. No. 7.

Hidayat, N. S. 2012. Studi Produksi dan Kualitas Rumput Gajah (Pennisetum Purpureum) Varietas Thailand yang Dipupuk dengan Kombinasi Organik. [Skripsi]. Purwokerto: Fakultas Peternakan Universitas Jendral Soedirman.

Ifradi. M. Peto dan Elsifitriana. 2003. Pengaruh Pemberian Pupuk Kandang Terhadap Produksi dan Nilai Gizi Rumput Gajah (Pennisetum Purpureum) Tanah Podzolik Merah Kuning. Jurnal Peternakan dan Lingkungan .

Janick, J. 1972. Horticultural Science. San Fransisco: W. H. Freeman and Co.

Kartasapoetra. 1988., Kesuburan dan Pemupukan Tanah Pertanian. Bandung: Pustaka Buana.

Kusuma, M. E. 2014. Respons Rumput Gajah (Pennisetum purpureum) terhadap Pemberiaan Pupuk Majemuk. Jurnal Hewani Tropika. Vol 3. No. 1.

Nasaruddin dan Rosmawati. 2011. Pengaruh Pupuk Organik Cair Hasil Fermentasi Daun Gamal, Batang Pisang Dan Sabut Kelapa Terhadap Pertumbuhan Kakao. Jurnal Agrissitem. Vol. 7 No. 1.

Purbayanty, E. D. 2013. Rumput dan Leguminosa sebagai Hijauan Makanan Ternak. Cetakan Pertama. Yogyakarta: Graha Ilmu.

Sari, R. M. 2012. Produksi dan Nilai Nutrisi Rumput Gajah (Pennisetum purpureum) cv. Taiwan yang diberi dosis pupuk $\mathrm{N}, \mathrm{P}$ dan $\mathrm{K}$ berbeda pada lahan kritis tambang batu bara. Artikel.

Setiawan, I. S. 2005. Memanfaatkan Kotoran Ternak. Jakarta: Penebar Swadaya.

Sitindaon, S. H. 2013. Inventarisasi Potensi Bahan Pakan Ternak Ruminansia Di Provinsi Riau. Jurnal Peternakan. Vol. 10 No. 1.

Subowo, G. 2010. Strategis Efisiensi Penggunaan Bahan Organik untuk Kesuburan dan Produktifitas Tanah Melalui Pemberdayaan Sumberdaya Hayati Tanah. Jurnal Sumberdaya Lahan. Vol. 4 No. 1.

Sumarsono, S., D. W. Anwar dan S. Budiyanto. 2009. Penerapan Pupuk Organik untuk Perbaikan Penampilan dan Produksi Hijauan Rumput Gajah pada Tanah Masam. Seminar Nasional Kebangkitan Peternakan. Semarang: Fakults Peternakan Universitas Diponogoro. 
Steel, R. G. D. and J. H. Torrie. 1993. Prinsip dan Prosedur Statistika: Suatu Pendekatan Biometrik. Sumantri, B. (Penerjemah). Terjemahan dari: Principles And Procedures Of Statistis. Jakarta: PT. Gramedia.
Sutejo, M. M. 2002. Pupuk dan Cara Pemupukan. Cetakan Ke 5. Jakarta: Rineka Cipta.

Available online at journal homepage: http://ojs3.unpatti.ac.id/index.php/agrinimal 